\title{
ВИЗНАЧЕННЯ ЕФЕКТИВНИХ НАПРЯМІВ ТА КРИТЕРІЇВ ІННОВАЦІЙНОЇ РОБОТИ В ГАЛУЗІ СОНЯЧНОЇ ЕНЕРГЕТИКИ
}

\author{
В.О. Пундєв, В.І. Шевчук, Н.В. Марченко
}

Інститут відновлюваної енергетики НАН України, 02094, вул. Гната Хоткевича, 20А, м. Київ, Україна,

Приведено огляд стану та розвитку в світі галузі виготовлення сонячних елементів, як базової одиниці фотоелектричнихмодулів, які виробляються та перебувають на стадї дослідження на сьогодні.

В статті сконцентровано увагу на чотирьох найвідоміших типах фотоелектричних модулів, які використовують сонячні елементи. При иъьму враховано як певні конструкторські відмінності в їх виготовленні, так $і$ техніко-економічні витрати, особливості експлуатачіï та утилізації після виходу модулів з експлуатації.

Розроблено методику аналізу фотоелектричних модулів з використанням методу парних порівнянь та встановлено критерії, що враховують їх техніко-економічні показники і ринкові фактори (на одиницю установленої потужності), а саме: вартість; вагу модуля; ККД модуля; екологічність утилізачії модулів після виходу з ладу або припинення терміну експлуатачії; особливості деградації кожного окремого типу модуля.

Проведено аналіз базових сегментів типів фотоелектричних модулів та визначено інтегральні оцінки для кожного сегмента. Найвищу інтегральну оцінку отримав сегмент модулів, виготовлених на основі монокристалічного кремнію, а найнижчусегмент модулів, виготовлених на базі СдТе. Друге і третє місия практично розділили між собою модулі на основі аморфного кремнію і на основі перовскитових структур.

3 огляду на результати цього аналізу запропоновано спрямувати інвестиції, залучені в розвиток галузі фотоенергетики, в сегмент модулів, які використовують тандемні сонячні елементи на базі монокристалічного кремнію і перовскитових структур. Заводи звиробнищтва сонячних елементів на базі кристалічного кремнію в Україні існують, а розробку та виготовлення перовскитових структур необхідно розвивати. Бібл. 9, табл. 5, рис. 1.

Ключові слова: фотоенергетика, ККД фотоелектричного модуля, сонячний елемент, вартість модуля на одиницю потужності, екологічність утилізації модулів.

\section{DETERMINATION OF EFFECTIVE DIRECTIONS AND CRITERIA OF INNOVATIVE WORK IN THE FIELD OF SOLAR ENERGY}

\section{Pundiev, V. Shevchuk, N. Marchenko}

Instituteof Renewable Energy of the National Academy of Sciences of Ukraine, 02094, 20A Hnata Khotkevycha St., Kyiv, Ukraine.

An overview of the state and development in the world of the solar cell industry as a basic unit of photovoltaic modules, which are produced and are at the research stage to date.

The article focuses on the four most well-known types of photovoltaic modules that use solar cells, taking into account both certain design differences in their manufacture and technical and economic costs, features of operation and disposal after decommissioning of modules. A method of analysis of photovoltaic modules using the method of pairwise comparisons has been developed and criteria have been established that take into account their technical and economic indicators and market factors (per unit of installed capacity), namely: cost; module weight; Module efficiency; environmental friendliness of module disposal after failure or termination of service life; features of degradation of each separate type of the module.

The analysis of basic segments of types of photovoltaic modules is carried out and integrated estimations for each segment are defined. The highest integrated score was received by the segment of modules made on the basis of single-crystal silicon, and the lowest-the segment 
of modules made on the basis of CdTe. The second and third places were practically shared by modules based on amorphous silicon and based on perovskite structures.

According to the results of this analysis, it is proposed to focus investments on the development of the photovoltaic industry in the segment of modules that use tandem solar cells based on single-crystal silicon and perovskite structures. Factories for the production of solar cells based on crystalline silicon exist in Ukraine, and the development and manufacture of perovskite structures must be developed. Ref. 9 , tab. 5, fig. 1.

Keywords: photovoltaics, photovoltaic module efficiency, solar cell, module cost per unit of power, environmental friendliness of module utilization.

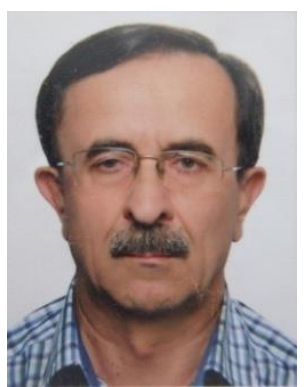

B.О.Пундєв V. Pundiev

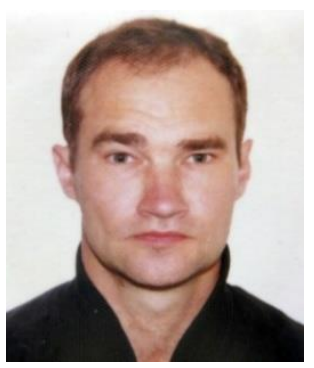

B.I. Шевчук V. Shevchuk

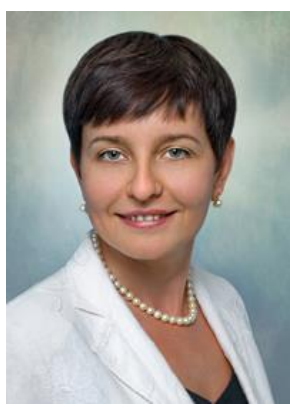

Н.В. Марченко N. Marchenko
Відомості про автора: науковий співробітник відділу сонячної енергетики в Інституті відновлюваної енергетики НАН України

Освіта: Ворошиловградський машинобудівельний інститут, факультет електромашинобудування, спеціальність «Електричні машини та апарати»

Наукова сфера: відновлювана енергетика, зокрема сонячна енергетика

Публікації: 26

ORCID:0000-0003-3750-8812

Контакти:+38(044)206-28-09

e-mail: renewable@ukr.net

Відомості про автора: науковий співробітник відділу сонячної енергетики в Інституті відновлюваної енергетики НАН України.

Освіта: Київський політехнічний інститут, електротехнічний факультет, спеціальність «Електричні станції»

Наукова сфера: відновлювана енергетика, зокрема сонячна фотоенергетика

Публікації: 41

ORCID: 0000-0002-4176-7799

Контакти: +38(044)206-28-09

e-mail: renewable@ukr.net

Відомості про автора: молодший науковий співробітник з питань маркетингових досліджень Інституту відновлюваної енергетики НАН України Освіта: Київський технологічний інститут легкої промисловості, спеціальність «Інженер-конструктор-технолог»

Наукова сфера: маркетинговий аналіз інноваційної діяльності в галузі відновлюваної енергетики

Публікації: 33

ORCID: 0000-0001-9921-9077

Контакти: +38-098-408-26-02

e-mail:nadija08@ukr.net
Autor information: Research Associate of Solar

Power Engineering Department of Institute of

Renewable Energy at NAS of Ukraine

Education: The Voroshilovgrad Machine-

Building Institute in Electrical Machines and

Devices

Research area: renewable power in particular solar power

Publications: 26

ORCID:0000-0003-3750-8812

Contacts:+38(044)206-28-09

e-mail: renewable@ukr.net

Autor information: Research Associate of Solar Power Engineering Department of Institute of Renewable Energy at NAS of Ukraine

Education: The Kyiv Polytechnic Institute in Power Plants

Research area:renewable power, in particular photovoltaics

Publications: 41

ORCID: 0000-0002-4176-7799

Contacts:+38(044)206-28-09

e-mail: renewable@ukr.net

Authorinformation: Junior Researcher on marketing researchatthe Institute of Renewable Energy of the National Academy of Sciences of Ukraine

Education: Kyiv National University of Technologies and Design, specialty Design Engineer - Technologist

Researcharea: marketing research in the field of renewable energy in novations

Publications: 33

ORCID: 0000-0001-9921-9077

Contacts:+38-098-408-26-02

e-mail: nadija08@ukr.net 
Вступ. Динамічний розвиток світової енергетики неможливий без детального дослідження і впровадження енергетичних систем, що використовують відновлювані джерела енергії (ВДЕ). Використання ВДЕ сприяє підвищенню рівня енергетичної безпеки, зменшує кількість шкідливих викидів в атмосферу та забезпечує швидкий шлях до покращення соціальнопобутових умов населення. До найперспективніших джерел відновлюваної енергії, використання яких економічно доцільне, належать: енергія Сонця, вітру, води та землі.

Розвиток та дослідження у галузі сонячної енергетики в Україні регламентуються: Законом України «Про енергозбереження» [1] та Законом «Про електроенергетику» (Стаття 17-1. Стимулювання виробництва електроенергії 3 альтернативних джерел енергії), що сприяє розвитку сонячної енергетики [2].

Окрім вказаних нормативних актів дослідження у галузі сонячної енергетики підтримуються державною цільовою програмою, розробленою відповідно до Постанови Президії Національної академії наук України № 55 від 25 лютого 2009 «Основні наукові напрями та найважливіші проблеми фундаментальних досліджень у галузі природничих, технічних i гуманітарних наук». У програмі визначені головні напрями наукових досліджень, пов'язані 3 сонячною енергетикою (фотоенергетика та теплоенергетика).

Постановка задачі дослідження. Для ефективного розвитку сонячної енергетики необхідно визначити напрями інвестування i, відповідно, напрями дослідження.

Для визначення ефективного напряму вкладання інвестицій та вибору об'єкта для інвестування існує ряд методів, а саме:
- метод ранжування;

- метод парних порівнянь;

- метод абсолютної оцінки;

- метод аналізу ієрархій;

- метод вибору.

Метод ранжування. Експерти оцінюють якість об'єктів за допомогою встановлення їх рангу (порядкового номера об'єкта, якщо всі об'єкти розташовують у порядку зростання їх якості). Чим більшу (меншу) суму рангів отримає об'єкт від усіх експертів, тим вища (нижча) його якість.

\section{Метод парних порівнянь.}

Використовується тоді, коли експерти можуть порівняти об'єкти між собою попарно і встановити кращий об'єкт у кожній парі. Кожен експерт заповнює свою таблицю порівнянь. Порівнюючи об'єкти кожної пари між собою, експерт записує номер (i чи j) кращого об'єкта з кожної пари.

Метод абсолютних оцінок. Цей метод передбачає використання числової шкали оцінок, межі якої визначено технічними характеристиками об'єкта. Оцінка являє собою фізичну величину в певних одиницях вимірювання [3].

Метод аналізу ісрархій (MAI) математичний інструмент системного підходу до складних проблем прийняття рішень. MAI не нав'язує особі, що приймає рішення, будь-якого «правильного» рішення, а дозволяє йому в інтерактивному режимі знайти такий варіант (альтернативу), щоякнайкраще узгоджується з його розумінням суті проблеми та вимогами до іï розв'язання.

Метод вибору. Пропонується кілька об'єктів (стимулів, висловлювань тощо), з яких він повинен вибрати ті, які відповідають заданому критерію.

У нашому випадку доцільно й ефективно використати метод парних порівнянь. 
Для проведення аналізу та визначення ефективних напрямів інноваційної роботи використаємо метод парних порівнянь, наведений в роботі [4]. Роботу з використанням цього методу проведемо в один етап, тобто визначимо найбільш технічноефективний модуль в технологічному плані.

Для використання методу парних порівнянь в галузі сонячної енергетики залучені експерти 3 маркетингових досліджень.

Аналіз та класифікація фотоелектричних модулів (ФЕМ). ФЕМ - пристрій, до складу якого входять електрично та конструктивно з'єднані між собою сонячні фотоелектричні елементи і який має вихідні клеми для підключення навантаги згідно 3 [5]. Переважна більшість модулів комплектується 3 окремих фотоелектричних елементів (ФЕ), принцип роботи яких побудований на основі явища фотоефекту в напівпровідниках. У фотоелектричних перетворювачах сонячної енергії здебільшого використовується кремній як головний матеріал для створення сонячного елемента 3 добавками інших хімічних елементів, що утворюють структуру з p-n-переходом.

Фотоелектричні модулі мають значні потенційні переваги порівняно 3 іншими електрогенерувальними пристроями:

- відсутність рухомих частин, що значно знижує експлуатаційні витрати;

- термін експлуатації 10-25 років за умови стабільності експлуатаційних характеристик;

- не потребують високої кваліфікації обслуговуючого персоналу;

- використовують як пряме, так і розсіяне (дифузне) випромінювання;

- придатні для створення установок практично будь-якої потужності.
Залежно від типу найпоширеніших сонячних елементів, які використовуються у фотоелектричних модулях, i технологій їх виконання існує такий розподіл їх на окремі основні групи:

а) кристалічні елементи на базі $\mathrm{Si}$;

б) багатоперехідні сонячні елементи;

в) одноперехідні сонячні елементи на базі GaAs;

г) сонячні елементи на базі плівкових технологій;

д) сонячні елементи з групи Emerging PV (дослідні зразки), які випробовуються в лабораторіях, мають порівняно великі перспективи.

Аналізуючи представлену Національною лабораторією США з відновлюваної енергетики (NREL) інформацію [6], можна зробити такі висновки:

1. Найефективнішими на сьогодні $\epsilon$ багатоперехідні сонячні елементи, які використовуються 3 концентраторами i мають стабільний графік зростання ККД протягом 40 років. Слід зазначити, що зі зростанням кількості переходів в елементі зростає і ККД.

2. Набули поширення сонячні елементи 3 групи Emerging PV, різноманіття яких з'явилося протягом останніх 10-15 років, а найбільш стрімке зростання ККД спостерігається у сонячних елементів на базі перовскитових структур.

3. Неухильно зростає ККД у сонячних елементів на базі плівкових технологій, які дещо поступаються у стрімкості зростання ККД сонячним елементам 3 групи Emerging PV, але мають відносно непогані перспективи щодо розвитку. Подібна картина помічається у кристалічних елементів на базі Si.

4. Найменший прогрес зростання ККД протягом 40 років помічено у групи одноперехідних сонячних елементів на базі GaAs. 
Для порівняльного аналізу виберемо три базові варіанти конструктивного і технологічного виконання сонячних фотоелектричних модулів, які $€$ найпоширенішими у світі, а також один варіант 3 нових розробок.

\section{Фотоелектричні} монокристалічними модулі фотоелектричними елементами серед кремнієвих кристалічних модулів мають найвищу ефективність перетворення енергії, але ці ФЕМ $є$ і більш дорогими в перерахунку на один ват потужності. Основний матеріал елементів цих модулів кремній надвисокої чистоти, найбільш поширений та застосовуваний у галузі виробництва напівпровідників. Технологія виготовлення монокристалічних кремнієвих елементів у спрощеному вигляді така. 3 кремнієвого розплаву витягуванням за допомогою способу Чохральського формуються кремнісві монокристали. Далі ці монокристали проходять ряд основних технологічних операцій:

- порізка на пластини;

- обточування, шліфування та очищення;

- нанесення захисних покриттів;

- металізація контактів;

- нанесення антивідбиваючого покриття.

ККД цих ФЕМ за умов серійного виготовлення зазвичай складає на сьогодні $20-22 \%$, хоча окремі дослідні зразки досягають $26 \%$ [6,7]. Здебільшого монокристалічні елементи мають форму чотирикутників або псевдоквадратів, якими можна заповнити майже всю площу фотоелектричної панелі без залишку. Тому питома потужність ФЕМ трохи нижча, ніж питома потужність окремого іï елемента. Одним 3 найбільших виробників фотоелектричних модулів 3 монокристалічних елементів в Україні є ПАТ «Квазар».
Серійні елементи Sunpower (США) i Sanyo(Японія) мають ефективність у межах $22 \%$. Але ця технологія усе ще $\epsilon$ досить дорогою, i відносна частка ринку ФЕМ марок Sunpower i Sanyo дуже незначна. На сьогоднішні домінує стандартна технологія з ККД сонячних модулів від 15 до $16,4 \%$ - це модулі, виконані 3 монокристалічних елементів 3 ефективністю від 17 до 19,5\%, використовувані в основному китайськими виробниками.

Фотоелектричні модулі 3 аморфного кремнію мають один 3 найнижчих ККД. Зазвичай його значення наразі складає $10-12 \%$. Однак серед усіх кремнієвих фотоелектричних перетворювачів вони $\epsilon$ найдешевшими i тому виробляють електроенергію 3 найнижчою ціною. Аморфний кремній для таких ФЕМ отримують за допомогою «технології випарної фази», коли тонка плівка кремнію осідає на несучий матеріал і захищається покриттям. Така технологія виробництва ФЕМ дозволяє обійтися без каркаса, вона порівняно нескладна і має як недоліки, так і переваги. Одним 3 основних виробників, що виготовляють ФЕМ за такою технологією, $є$ Bosch Solar Energy AG (Німеччина). До переваг цієї технології належать:

- процесс виробництва сонячних панелей на основі аморфного кремнію порівняно простий $\mathrm{i}$ недорогий;

- не потребує високої чистоти матеріалу;

- модуль може мати різні геометричні форми залежно від вимог замовника;

- можливе виробництво елементів відносно великої площі;

- 3 погляду екології виробництво і сам матеріал - найбезпечніші для довкілля; 
- елементи ефективніші при роботів умовах розсіяного випромінювання порівнянні 3 елементами на основі CIGS або кристалічного кремнію;

- сфера застосування значно ширша, ніж в елементів кристалічного типу.

До основних недоліків можна віднести такі:

- ефективність перетворення сонячної енергії в електричну значно нижча, ніж у кристалічних елементів;

- процесс деградації у цих елементів відбувається швидше, ніж у кристалічних елементів, тому вони мають термін експлуатації значно менший [6].

\section{Фотоелектричні модулі з телуриду кадмію} (CdTe) виготовляють на основі плівкової технології. Напівпровідникову плівку наносять на несний матеріал тонким шаром у кілька сотень мікрометрів. Ефективність модулів 3 телуриду кадмію невелика і становить на сьогодні $14-16 \%$, хоча окремі дослідні зразки досягають показника $23 \%$. Проте порівняно 3 кремнієвими панелями один ват потужності цих ФЕМ є на кілька десятків відсотків дешевшим. Одними 3 найбільших виробників таких модулів є фірми: GE Energy та First Solar (США), Longyan Energy Technology (Китай).

До переваг фотоелектричних модулів 3 телуриду кадмію належать:

- висока напруга;

- низька вартість;

- відсутність кремнію в складі сонячних елементів, що обумовлює більш спрощену технологію виробництва;

- більший ККД в похмурі дні порівняно 3 ФЕМ із кристалічного кремнію;

Недоліки цих модулів такі:
- $\quad$ негативно діють на довкілля й потребують спеціальної утилізації, оскільки до їх складу входять кадмій - небезпечний токсичний хімічний елемент і телур, що належить до рідкоземельних металів.

Фотоелектричні елементи на основі перовскитових структур [8]. Перовскит природний мінерал, який $є$ в достатній кількості в земній корі. Фотоелектричні елементи на основі перовскитових структур можна створювати 3 включенням різних матеріалів 3 відповідною кристалічною структурою, яка забезпечує їx напівпровідникові властивості. Інколи їх називають гібридними фотоелектричними елементами на основі перовскитових структур, бо вони мають кращі характеристики різних фотоелектричних елементів.

Перспективним може стати застосування перовскитових структуру поєднанні 3 іншими сонячними елементами шляхом створення багатошарових елементів. У таких пристроях кожен шар відповідає за перетворення в електричний струм певної хвилі сонячного випромінювання. Це так звані тандемні сонячні елементи, які вже показали ефективність вище $40 \%$, що вдвічі більше, ніж мають традиційні сонячні панелі, які широко представлені сьогодні на ринку.

Сонячні елементи цього типу мають кристалічну структуру, схожу 3 кристалічною решіткою перовскиту - мінералу титанату кальцію, $\mathrm{CaTiO}_{3}$. Найбільш вивчена формула перовскитової структури, яка використовується в сонячній енергетиці, - $\mathrm{CH}_{3} \mathrm{NH}_{3} \mathrm{PbX}_{3}$, де $\mathrm{CH}_{3} \mathrm{NH}_{3}-$ іон метиламонію, $\mathrm{Pb}$ - свинець, a $\mathrm{X}$ - іон 3 числа галогенів (може бути як I, Br, так і Cl). Кристалічна решітка такого перовскиту представлена на рис.1. Атоми розміщені в псевдокубах у вузлах слабо 
спотвореної кубічної решітки. В центрах псевдокубів розміщуються атоми свинцю (інколи може бути й олово). Атоми галогенів утворюють навколо атомів свинцю практично правильні октаедри, які трішки розгорнуті та нахилені відносно ідеальних положень.
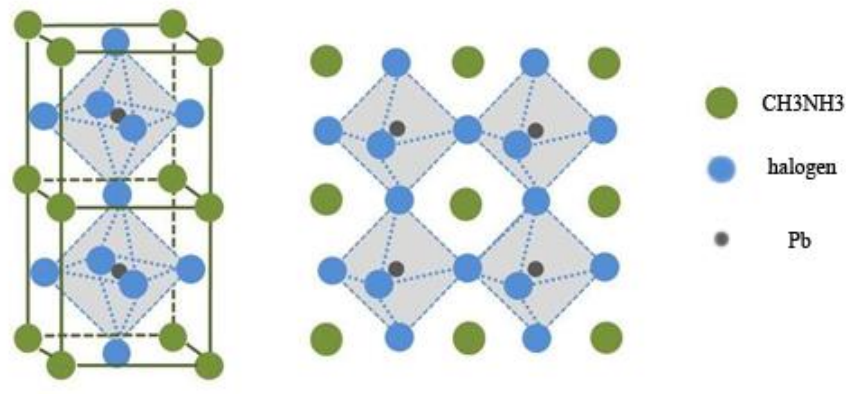

Рис. 1. Кристалічна решітка перовскиту

Fig.1 Perovskite crystallattice of.

Головними

проблемами використання перовскитових структуру

щодо сонячній енергетиці $\epsilon$ їх нестабільність кристалічна структура легко руйнується (особливо під дією кисню та вологи), а також наявність свинцю, який належить до шкідливих металів. У перших дослідах життєвий цикл перовскитових структур вимірювався годинами, але останніми роками його вдалося збільшити до шести тижнів. Очевидним напрямом покращення перовскитових технології $\epsilon$ ефективний захист матеріалу від впливу повітря та вологи.

\section{Невирішені питання й постановка} задачі. Кожний 3 розглянутих типів фотоелектричних модулів має свої недоліки та переваги. Тому постає питання, які ж фотоелектричні модулі найбільш доцільні для подальших досліджень, розробки та впровадження. Тож метою даної роботи є як розробка методики так і проведення на її основі експертного порівняльного аналізу типів фотоелектричних модулів методом парних порівнянь на основі таких критеріїв: коефіцієнт корисної дії, деградація фотоелектричних модулів, вартість продукції, вага, екологічність утилізації тощо.

Завданням дослідження є визначення на основі експертних оцінок та математичних розрахунків типів фотоелектричних модулів 3 найбільшою інтегральною оцінкою i потенціалом для наступного їх дослідження, розробки та впровадження в народне господарство.

\section{Визначення критеріїв для} порівняльного аналізу фотоелектричних модулів.

Для виконання порівняльного аналізу було прийнято такі вихідні критерії:

$$
\mathrm{X}_{1}-\text { коефіцієнт корисної дії (ККД) }
$$
фотоелектричного модуля. Коефіцієнт визначає, яку частину сонячної енергії модуль перетворює в електричну.

$\mathrm{X}_{2}$ - деградація фотоелектричних модулів. Цей критерій показує втрату електрофізичних характеристик фотоелектричного модуля залежно від терміну експлуатації.

$\mathrm{X}_{3}$ - вага (модуля або сонячного елемента на сьогодні), яка дозволяе крім наземного розташування розміщувати модулі на дахах, фасадах і стінах будівель різного призначення.

$\mathrm{X}_{4}$ - екологічність; характеризує затрати на утилізацію фотоелектричного модуля, який вийшов 3 ладу або частково втратив свої електрофізичні властивості.

$\mathrm{X}_{5}-$ вартість продукції (модуля або сонячного елемента на сьогодні).

Найбільший ККД є у сонячних елементів 3 перовскитовими структурами, які належать до тандемних елементів. 
До найбільш екологічно чистих фотоелектричних модулів належать ФЕМ 3 аморфного кремнію. Для них показник екологічності приймемо за 1,0 а інші будуть мати показники, виражені у відсотках від екологічно чистого ФЕМ 3 аморфного кремнію. Найбільш важливим $є$ те, що аморфний кремній не має шкідливого впливу на екологію за умов їх виготовлення та функціонування. Це найбезпечніші модулі. На другому місці - ФЕМ на базі монокристалічних фотоелектричних кремнієвих елементів 3 показником екологічності 0,6 які безпечні на стадії експлуатації, хоча значно небезпечні на стадії очищення кремнію. На третьому і четвертому місцях розмістимо модулі 3 елементими CdTe i перовскитових структур $\left(\mathrm{CH}_{3} \mathrm{NH}_{3} \mathrm{PbX}_{3}\right)$ з показником 0,3. Хімічні елементи $\mathrm{Cd}$, Te та $\mathrm{Pb}$ можуть негативно впливати на довкілля в разі безконтрольної утилізації .

Існуючі варіанти технологічного виконання сонячних фотоелектричних модулів:

$$
\text { P1 - фотоелектричні модулі } 3
$$

монокристалічних кремнієвих фотоелектричних елементів;

Таблиця 1. Вхідні дані для проведення аналізу

Table1. Input data for analysis

\begin{tabular}{|c|c|c|c|c|c|c|}
\hline \multirow{4}{*}{ Критерії } & \multirow{4}{*}{$\begin{array}{c}\text { Одиниці } \\
\text { вимірю- } \\
\text { вання }\end{array}$} & \multirow{4}{*}{$\begin{array}{c}\text { Індекс } \\
\text { параметра }\end{array}$} & \multicolumn{4}{|c|}{ Типи фотоелектричних модулів } \\
\hline & & & 1 & 3 & 4 & 2 \\
\hline & & & $\begin{array}{c}\text { Фотоелектричні } \\
\text { модулі на основі } \\
\text { перовскитових } \\
\text { структур }\end{array}$ & $\begin{array}{c}\text { Фотоелектричні } \\
\text { модулі з } \\
\text { аморфного } \\
\text { кремнію }\end{array}$ & $\begin{array}{l}\text { Фотоелектричні } \\
\text { модулі } 3 \\
\text { телуриду } \\
\text { кадмію }\end{array}$ & $\begin{array}{c}\text { Фотоелектричні } \\
\text { модулі } 3 \\
\text { монокристалічних } \\
\text { кремнієвих } \\
\text { фотоелектричних } \\
\text { елементів }\end{array}$ \\
\hline & & & $\mathrm{P} 1$ & $\mathrm{P} 2$ & P3 & $\mathrm{P} 4$ \\
\hline $\begin{array}{l}\text { Коефіцієнт } \\
\text { корисної дії }\end{array}$ & $\%$ & $\mathrm{X}_{1}$ & 20 & $10-12$ & $14-16$ & $20-22$ \\
\hline \begin{tabular}{|l|} 
Деградація \\
фотоелект- \\
ричних \\
модулів
\end{tabular} & $\% /$ рік & $\mathrm{X}_{2}$ & 120 & 0,87 & 0,4 & 0,36 \\
\hline Вага модуля & Кг & $\mathrm{X}_{3}$ & 1,0 & 1,0 & 1,0 & 0,6 \\
\hline $\begin{array}{l}\text { Екологічність } \\
\text { Утилізації }\end{array}$ & грн/Вт & $\mathrm{X}_{4}$ & 0,3 & 1,0 & 0,3 & 0,6 \\
\hline \begin{tabular}{|l} 
Вартість \\
сонячного \\
елемента \\
або модуля \\
\end{tabular} & $\$$ & $\mathrm{X}_{5}$ & $10-20$ & 60 & 67,5 & 105 \\
\hline
\end{tabular}


Метод парних порівнянь передбачає процес ранжування вибраних критеріїв за ступенем важливості. Для цього кожному 3 обраних параметрів присвоєно індекс у відповідності до їх розташування у табл. 1. Маючи кількість критеріїв $\mathrm{n}$, розраховується необхідна кількість порівнянь $\mathrm{p}$ за формулою:

$$
p=\frac{n(n-1)}{2}, \text { (шт.). }
$$

Для кількості критеріїв $\mathrm{n}=5$ будемо мати необхідну кількість порівнянь $\mathrm{p}=10$.

При парному порівнянні обраних критеріїв використано три ступеня їх вагомості: більш вагомий - оцінка 1,5 , менш вагомий - оцінка 0,5 та рівнозначні між собою - оцінка 1. Відповідно до методики опитано чотири незалежних респондента, кожному 3 яких запропоновано порівняти попарно критерії $\mathrm{X}_{1}-\mathrm{X}_{5}$ та вибрати 3 кожної пари більш вагомий параметр для фотоелектричних модулів. Число експертів було визначено за умови, щоб їх кількість відповідала числу досліджуваних критеріїв. Збільшення кількості респондентів не приведе до суттєвої загальної інтегральної оцінки вибраних конструктивних та технологічних рішень ФЕМ.

Остаточну (середню) оцінку ступеня важливості кожного з вибраних критеріїв отримано як результат зіставлення оцінок кожного 3 експертів за формулою:

$$
\left.K_{1}=\frac{\sum_{i=1}^{m} B_{i}}{m}, \text { (балів }\right),
$$

де $B_{i}-$ числове значення ступеня вагомості критерію, визначене кожним експертом; m - число експертів.

Для другого 3 двох порівнюваних критеріїв середня оцінка $K_{2}$ визначається за формулою:

$$
K_{2}=2-K_{1} .
$$

Остаточні середні оцінки ступенів важливості кожного з критеріїв наведено в табл. 2.

\begin{tabular}{|c|c|c|c|c|c|c|}
\hline \multirow{2}{*}{$\begin{array}{c}\text { Критерії, які } \\
\text { порівнюються }\end{array}$} & \multicolumn{4}{|c|}{ Експертна оцінка } & \multicolumn{2}{|c|}{$\begin{array}{c}\text { Середня оцінка } \\
\text { порівнюваних параметрів }\end{array}$} \\
\hline & Експерт 1 & Експерт 2 & Експерт 3 & Експерт 4 & $\mathrm{~K}_{1}$ & $\mathrm{~K}_{2}$ \\
\hline $\mathrm{X}_{1}-\mathrm{X}_{2}$ & 1,5 & 1,5 & 1,0 & 1,5 & 1,375 & 0,625 \\
\hline $\mathrm{X}_{1}-\mathrm{X}_{3}$ & 1,5 & 1,5 & 1,5 & 1,5 & 1,5 & 0,5 \\
\hline $\mathrm{X}_{1}-\mathrm{X}_{4}$ & 1,5 & 1,0 & 1,0 & 1,0 & 1,125 & 0,875 \\
\hline $\mathrm{X}_{1}-\mathrm{X}_{5}$ & 1,5 & 1,5 & 1,5 & 1,5 & 1,125 & 0,875 \\
\hline $\mathrm{X}_{2}-\mathrm{X}_{3}$ & 1,5 & 1,5 & 1,5 & 1,5 & 1,5 & 0,5 \\
\hline $\mathrm{X}_{2}-\mathrm{X}_{4}$ & 1,0 & 1,0 & 1,0 & 1,0 & 1,0 & 1,0 \\
\hline $\mathrm{X}_{2}-\mathrm{X}_{5}$ & 1,0 & 1,0 & 1,0 & 1,0 & 1,0 & 1,0 \\
\hline $\mathrm{X}_{3}-\mathrm{X}_{4}$ & 0,5 & 0,5 & 0,5 & 0,5 & 0,5 & 1,5 \\
\hline $\mathrm{X}_{3}-\mathrm{X}_{5}$ & 0,5 & 0,5 & 0,5 & 0,5 & 0,5 & 1,5 \\
\hline $\mathrm{X}_{4}-\mathrm{X}_{5}$ & 1,0 & 1,0 & 1,0 & 1,0 & 1,0 & 1,0 \\
\hline
\end{tabular}

Таблиця 2. Визначення вагомості критеріїв експертами

Table 2. Determining the importance of criteria by experts

На основі даних експертної оцінки заповнено таблицю пріоритетів критеріїв (табл. 3). Значення, що розташовані вище головної діагоналі матриці в табл. 3, відповідають середнім оцінкам $K_{1}$ в табл. 2, а значення, що розташовані нижче головної діагоналі- оцінкам $K_{2}$. Коефіцієнт пріоритету розраховано для кожного рядка таблиці за формулою:

$$
K_{\text {пр }}=\frac{\sum_{i=1}^{m-1} K_{i}}{n(n-1)}(\text { балів }),
$$

де: $\sum_{i=1}^{m-1} K_{i}-$ сума ряду в табл. $3 ; \mathrm{n}-$ кількість порівнюваних критеріїв. 
Таблиця 3. Визначення пріоритету критеріїв

Table 3. Determining the priority of criteria

\begin{tabular}{|c|c|c|c|c|c|c|c|c|}
\hline \multirow{2}{*}{$\begin{array}{c}\text { Індекс } \\
\text { критерію }\end{array}$} & $\mathrm{X}_{1}$ & $\mathrm{X}_{2}$ & $\mathrm{X}_{3}$ & $\mathrm{X}_{4}$ & $\mathrm{X}_{5}$ & \multicolumn{2}{|c|}{ Визначення пріоритету } & \multirow{2}{*}{$\begin{array}{c}\text { Пріоритет } \\
\text { критерію }\end{array}$} \\
\hline $\mathrm{X}_{1}$ & $\mathrm{X}$ & 1,375 & 1,5 & 1,125 & 1,125 & 5,125 & 0,256 & 1 \\
\hline $\mathrm{X}_{2}$ & 0,625 & $\mathrm{X}$ & 1,5 & 1,0 & 1,0 & 4,125 & 0,206 & 4 \\
\hline $\mathrm{X}_{3}$ & 0,5 & 0,5 & $\mathrm{X}$ & 0,5 & 0,5 & 2,0 & 0,1 & 5 \\
\hline $\mathrm{X}_{4}$ & 0,875 & 1,0 & 1,5 & $\mathrm{X}$ & 1,0 & 4,375 & 0,218 & 2 \\
\hline $\mathrm{X}_{5}$ & 0,875 & 1,0 & 1,5 & 1,0 & $\mathrm{X}$ & 4,375 & 0,218 & 3 \\
\hline
\end{tabular}

На основі вхідних даних (табл. 1) виконано бальне оцінювання (Б) кожного критерію; оцінювалося кожне значення відповідно до ступеня ïх доцільності у технологічному процесі. Критеріям, що відповідають технічним вимогам найкраще, присвоюється значення 10 балів; близьким до найкращих 8-9 балів; достатнім 4-7 балів; близьким до достатніх 2-3 бали; недостатнім 0-1 бал. Результати бальної оцінки занесено до табл. 4.

Таблиця 4. Бальне оцінювання параметрів (Б)

Table 4. Scoring of parameters (B)

\begin{tabular}{|l|c|c|c|c|c|}
\hline \multirow{2}{*}{ Типи фотоелектричних модулів } & \multicolumn{5}{|c|}{ Бальна оцінка характеристик } \\
\cline { 2 - 6 } & $\mathrm{X}_{1}$ & $\mathrm{X}_{2}$ & $\mathrm{X}_{3}$ & $\mathrm{X}_{4}$ & $\mathrm{X}_{5}$ \\
\hline $\begin{array}{l}\text { ФЕМ з монокристалічних фотоелектричних кремнієвих } \\
\text { елементів }\end{array}$ & 9 & 8 & 7 & 10 & 8 \\
\hline ФЕМ на основі перовскитових структур & 10 & 7 & 10 & 3 & 10 \\
\hline ФЕМ з аморфного кремнію & 6 & 10 & 8 & 6 & 10 \\
\hline ФЕМ з телуриду кадмію & 8 & 2 & 7 & 9 & 10 \\
\hline
\end{tabular}

Після виконання бального оцінювання і визначення вагомості критеріїв, отримано інтегральні оцінки кожного критерію. Результати наведено в табл. 5.

Таблиця 5. Інтегральна оцінка технологічних виконань ФЕМ

Table 5. Integra evaluation of technological performances of PV modules

\begin{tabular}{|c|c|c|c|c|c|c|c|}
\hline \multirow[b]{2}{*}{ Вид конструкції } & \multicolumn{5}{|c|}{ Інтегральна оцінка } & \multirow{2}{*}{$\begin{array}{c}\text { Сума } \\
\text { інтеграль- } \\
\text { них } \\
\text { оцінок }\end{array}$} & \multirow{2}{*}{$\begin{array}{c}\text { Пріори- } \\
\text { тет } \\
\text { техноло- } \\
\text { гї̈ } \\
\end{array}$} \\
\hline & $\mathrm{K}_{\mathrm{np}_{1}}{ }^{*} \mathrm{~b}$ & $\mathrm{~K}_{\mathrm{np}_{2}}{ }^{* 5}$ & $\mathrm{~K}_{\mathrm{np}_{3}}{ }^{* 5}$ & $\mathrm{~K}_{\mathrm{np}_{4}}{ }^{*} \mathrm{~b}$ & $\mathrm{~K}_{\mathrm{np}_{5}}{ }^{* 5}$ & & \\
\hline $\begin{array}{l}\text { ФЕМ з монокристалічних } \\
\text { фотоелектричних кремнієвих } \\
\text { елементів }\end{array}$ & $0,256 * 9$ & $0,206 * 8$ & $0,1 * 7$ & $0,218 * 10$ & $0,218 * 8$ & 8,57 & 1 \\
\hline $\begin{array}{l}\text { ФЕМ на основі } \\
\text { перовскитових структур }\end{array}$ & $0,256 * 10$ & $0,206 * 7$ & $0,1 * 10$ & $0,218 * 3$ & $0,218 * 10$ & 7,83 & 3 \\
\hline ФЕМ з аморфного кремнію & $0,256 * 10$ & $0,206 * 10$ & $0,1 * 8$ & $0,218 * 6$ & $0,218 * 10$ & 7,88 & 2 \\
\hline ФЕМ з телуриду кадмію & $0,256 * 10$ & $0,206 * 2$ & $0,1 * 7$ & $0,218 * 9$ & $0,218 * 10$ & 7,3 & 4 \\
\hline
\end{tabular}


Підсумовуючи вищенаведені викладки можна констатувати, що для підвищення рівня енергобезпеки держави та зменшення впливу на довкілля на сьогодні головна увага в розвитку сонячної енергетики повинна бути зосереджена на ФЕМ 3 монокристалічних фотоелектричних кремнієвих елементів і, відповідно, дослідження, розробка та інвестиції мають бути зосереджені на даному типі ФЕМ. Але, як показують дослідження, особливу увагу в майбутньому потрібно приділити ФЕМ на базі аморфного кремнію, які на сьогоднішній день $€$ найбільш актуальними у порівнянні з іншими типами модулів, оскільки ці ФЕМ знаходяться у стадії розвитку: продовжується удосконалення технології виробництва, підняття ККД та їх експлуатація та утилізація не створюють екологічних проблем.

В Україні технологій виробництва ФЕМ 3 телуриду кадмію та на основі перовскитових структур поки немає. У цих технологіях не використовують високоочищений кремній як головну складову частину сонячного фотоелектричного елемента, але вживають такий токсичний і небезпечний метал, як кадмій, що належить до 2-го класу небезпечності, й токсичний свинець. Це теж прогресивні технології, які сприяють росту ККД у ФЕМ і зниженню енергозатратності підприємств. На сьогодні у дослідних зразків для ФЕМ на основі перовскитових структур ККД сягає понад $20 \%$. Слід також зазначити, що сьогодні крива зростання ККД у перовскитових структур значно переважає за темпами зростання ККД криву CdTe.

Наразі сонячні елементи на базі перовскитових структур об'єднують 3 іншими вищевказаними фотоелектричними елементами (отримуючи тандемні елементи). Це дуже перспективний напрям розвитку фотоенергетики.

Висновки. 1. Для визначення ефективних напрямів інноваційної роботи в галузі сонячної енергетики та розробки критеріїв ефективності було запропоновано метод парних порівнянь.

2. Визначені такі критерії аналізу: ККД, екологічність утилізації, рівень деградації, вартість продукції і вага фотоелектричних модулів.

3. Виконано порівняльний аналіз чотирьох базових типів ФЕМ і отримано їх інтегральні оцінки. Найвищу інтегральну оцінку 8,57 мають ФЕМ 3 монокристалічних фотоелектричних кремнієвих елементів. ФЕМ з елементами на основі перовскитових структур та з аморфного кремнію 7,83 і 7,88 відповідно. ФЕМ 3 телуриду кадмію - 7,3.

4. Головним технічним критерієм щодо вибору будь-якої ФЕМ є ККД. На другому місці екологічність утилізації, на третьому- вартість продукції, на четвертому - рівень деградації, а на п’ятому - вага фотоелектричних модулів.

5. Ефективним інвестуванням в галузі фотоенергетики може бути поєднання в одному ФЕМ електричного кола монокристалічних фотоелектричних кремнісвих елементів 3 колом 3 елементами на основі перовскитових структур.

1. Закон України «Про енергозбереження». [Електронний ресурс]. URL: https://zakon.rada.gov.ua/laws/sho w/74/94-\%D0\%B2\%D1\%80\#Text (дата звернення: 10.04.2021)

2. Закон України «Про електроенергетику». [Електронний ресурс]. URL: https://zakon.rada.gov.ua/laws/sho w/575/97-\%D0\%B2\%D1\%80\#Text (дата звернення 29.06.2019)

3.Формування експертних оцінок та оцінка узгодженості експертів. [Електронний ресурс]. URL: http://pidruchniki.ws/17190512/menedzhment/formuvannya ekspertnih otsinok otsinka uzgodzhenosti ekspertiv (дата звернення: 10.03.2021). 
4.Коханєвич В.П., Душина Г.П., Марченко Н.В., Романченко Д.С. Аналіз конструкцій вітрових енергетичних установок. Науковий журнал «Енергетика, економіка, технології, екологія». № 2. 2012. С. 61-66.

5.ДСТУ7503:2014. Геліоенергетика. Станції фотоелектричні. Терміни та визначення понять. Введ. 01.01.2015. К. Держспоживстандарт України. 2015. 13 с.

6.Зростання ефективності найкращих сонячних елементів протягом 45 років, графік. [Електронний ресурс]. URL:_ https://www.nrel.gov/pv/cell-efficiency.html. (дата звернення: 27.03.2021).

7.Ankita Gaurand G.N. Tiwari Performance of Photovoltaic Modules of Different Solar Cells.

8.Шамин, А.А., Ракша С.В., Кондрашин В.И., Печерская Р.М. Солнечные ячейки на основе перовскитов. Текст. непосредственный. Молодой ученый. 2015. № 4(84). С. 286-289. [Електронний ресурс]. URL: https://moluch.ru/archive/84/15652/ (дата звернення: 04.02.2020).

9. Розен В.П., Соловей А.И., Беламев А.А. Методические указания для работы студентов по лабораторному практикуму по курсам «Модели и методы оптимизации систем электроснабжения», «Автоматизированные системы управления и переработки информации» и «Энергетический менеджмент». К. 1999. 27 с.

\section{REFERENCES}

1. Zakon Ukrainy "Pro energozberezhennya". [Law of Ukraine "On Energy Saving"]. [Electronic resource]. URL: https://zakon.rada.gov.ua/laws/show/74/94-

\%D0\%B2\%D1\%80\#Text (Applying date: 10.04.2021). [in Ukrainian].

2. Zakon Ukrainy "Pro electroenergetyku". [Law of Ukraine "On Electricity"]. [Electronic resource]. URL: https://zakon.rada.gov.ua/laws/show/575/97-

\%D0\%B2\%D1\%80\#Text (Applying date: 29.06.2019). [in Ukrainian].
3. Formuvannya expertnyh ocinok ta ocinka uzgodzhenosti expertiv. [Formation of expert assessments and assessment of consistency of experts]. [Electronic resource]. URL: http://pidruchniki.ws/17190512/menedzhment/formuvannya_eksp ertnih_otsinok_otsinka_uzgodzhenosti_ekspertiv (Applying date: 10.03.2021). [in Ukrainian].

4.Kochanevich V.P., Dushina G.P., Marchenko N.V., Romanchenko D.S. Analis konstrukciy vitrovykh energetychnykh ustanovok. [Analysis of wind power plant designs]. Naukovy zhurnal «Energetyka, economika, tekhnologiyi, ecologiya». No. 2. 2012. Pp. 61-66. [in Ukrainian].

5.DSTU 7503:2014. Gelioenergetyka. Stanciyi photoelectrychni. Terminy ta vyznachennya ponyat. [Solar energy.Photovoltaic stations. Terms and definitions]. Vved. 01.01.2015. K. Derzhspozhyvstandart Ukrayiny. 2015. 13 p. [in Ukrainian].

6. Zrostannya efektyvnosti naikrashchyh sonyachnyh elementiv protyagom 45 rokiv, graphic. [Best research-cell efficiency]. URL: https://www.nrel.gov/pv/cell-efficiency.html. (Applying date: 27.03.2021).

7. Ankita Gaurand G.N. Tiwari Performance of Photovoltaic Modules of Different Solar Cells. [in English].

8. Shamin A.A., Raksha S.V., Kondrashin V.I., Pecherskaya P.M. Solnechnye yacheyki na osnove perovskitov. [Perovskite based solar cells]. Molodoy ucheny. 2015. No. 4(84). Pp. 286-289. [Electronic resource]. URL: https://moluch.ru/archive/84/15652/ (Applying date: 04.02.2020). [in Ukrainian].

9. Rozen V.P., Solovey A.I., Belashev A.A. Metodicheskie ukazaniya dlya raboty studentov po laboratornomu practikumu po kursam «Modeli i metody optimizaciyi system electrosnabzheniya», «Avtomatizirovannye sistemy upravleniya $\mathrm{i}$ pererabotki informaciyi» и «Energeticheskiy menejment». [Methodical instructions for work of students on laboratory workshop on courses "Models and methods of optimization of power supply systems", "Automated control systems and information processing" and "Energy management"]. K. 1999. 27 p. [in Ukrainian]. 